\title{
Cultural heritage tourism and authenticity: San Antonio Missions Historic District
}

\author{
S. Doganer \& W. Dupont \\ The University of Texas at San Antonio, College of Architecture, USA
}

\begin{abstract}
This research investigates and analyzes the potential of the San Antonio Missions Historic District towards community-based cultural heritage tourism. The accelerating tourism in South San Antonio brings considerable economic and social benefit through workforce, income and infrastructure developments.

Cultural heritage tourism is traveling to experience the places and activities that authentically represent the stories and people of the past and present. It is an economic development tool designed to attract visitors to an area based on the unique aspects of the locality's history, landscape and culture. This boosts regional and local pride and is a good source of revenue and jobs. Historic preservation is a tool for preserving a historic place, incubating small businesses, revitalizing downtowns, generating local jobs, and creating improvements in a community. It is estimated that between 35 and 40 percent of tourism today represents cultural tourism or heritage tourism. As an alternative to mass tourism, cultural and heritage tourism offer opportunities for place-based engagement that frames contexts for interaction with the "lived space" and "everyday life” of other peoples as well as sites of global heritage value.

World Heritage designation usually brings international attention and increased tourism with both positive and negative impacts. Cultural heritage tourism can bring many benefits to a local economy but it can also disrupt the quality of life of the local inhabitants. Authenticity is also critical whenever heritage is involved in tourism activities. This paper highlights the potential benefits for small business owners to connect to the growing heritage tourism economy of the San Antonio Missions Historic District. Prosperity for residents of the district is a viable path to sustaining the community's cultural heritage, identity and authenticity. This research also investigates how to prevent
\end{abstract}


gentrification and the loss of authenticity while tourism in the district accelerates.

Keywords: cultural heritage tourism, authenticity, sustainability, communitybased design.

\section{Introduction}

In the fields of architecture and historic preservation, the term "cultural heritage" is typically used in connection with conservation of the built environment. Cultural heritage is embodied in the built environment of a place, and is the evidence of past human endeavours. When present, cultural heritage has sociopolitical and economic values. One of these values that is both social and economic concerns cultural heritage tourism. When a historic place has a unique identity, and includes designated cultural heritage attractions such as the San Antonio Missions National Historical Park, managed by the US National Park Service, people visit as tourists. The cultural heritage thus becomes an asset with market and non-market values.

San Antonio was the last major American town connected by railroad. After a century and a half of relative isolation, San Antonio's appearance and customs were eccentric, and outsiders were drawn by curiosity [4]. Today, San Antonio is one of the State's top tourist cities. The city has a rich and unique historic urban landscape characterized by its river with its famous 'Riverwalk', historic neighborhoods and major landmarks such as The Alamo and the other San Antonio Missions. The San Antonio Missions play an important role in defining the city's culture. They are on the US "tentative list" to be advanced as a possible UNESCO World Heritage Site. Collectively, Missions Concepción, San José, San Juan, and Espada and associated features - including acequias (irrigation canals), labores (farm lands), dam and aqueduct, and the single remaining rancho (mission ranch) - comprise the San Antonio Missions National Historical Park [5].

In 2009, over 1.7 million people visited Missions Concepción, San José, San Juan, and Espada while 26 million people visiting the city San Antonio in total. San Antonio River Improvement Project and the possible World Heritage designation of the San Antonio Missions will bring international attention to the district, accelerate cultural heritage tourism, and provide "high profile catalyst" for even more cultural visitations [6].

This research investigates and analyzes the potential of the San Antonio Missions Historic District towards community-based cultural heritage tourism. The authenticity of heritage in the District is related to the tourism development. Accelerating tourism in the San Antonio Missions Historic District brings considerable economic and social benefit through workforce, income and infrastructure developments. This paper proposes a model project to support and connect community small business owners to the existing heritage tourism economy, and assist them in rehabilitation of their existing structures and properties. The purpose of the study is to foster prosperity for residents of the 
district. This in turn, will sustain the community’s cultural heritage and identity, and prevent loss of authenticity.

\section{San Antonio Missions Historic District}

The Missions Historic District spans nearly eight miles in south San Antonio, encompassing four San Antonio Missions sited along the San Antonio River. These eighteenth-century complexes include monumental stone buildings built in the Spanish Vernacular tradition, along with associated farmlands and acequias [7].

The historic San Antonio River has long served as the heart of the city. Each year the world-renowned River Walk draws millions of visitors, yet miles of urban river with untapped potential lie beyond downtown and the famed Paseo del Rio. A comprehensive, multi-year project is underway to restore and enhance 13 miles of the San Antonio River both north and south of downtown. The Mission Reach segment of the project overlays with the research area of this paper, and provides a strong connection between the area and downtown. It is expected that the river improvement project will also reinforce the connection to the San Antonio Missions, and encourage visitors to circulate along the river beyond the downtown area.

Some mid-nineteenth century residential properties remain in the Missions Historic District as well. Development in the surrounding area mostly dates from the late nineteenth century to the mid-twentieth century, including simple and modestly scaled residential and commercial buildings [7].

San Antonio River South Area Coordinated Management Plan [8] defines the demographic profile of the area as below:

"Between 1990 and 2008 the population within this area decreased slightly (-1\%) while San Antonio increased by 37\%. Residents within the corridor are 5\% of the City's total population (approximately $66,000)$ and density averages 4.92 persons per acre... Almost $43 \%$ of the population 25 years and older in this area has not completed a high school education... Educational attainment ties with income potential and discretionary spending. This area earns $\$ 30,630$, nearly $\$ 11,000$ less than the City average... Housing data shows that most residential structures account for $23 \%$ of the land use. They were built during the post WWII era and have a current median value of $\$ 54,843$ compared to the City of San Antonio average of $\$ 113,988 . ”$

Analysis reveals numerous challenges to the area such as: declining population, lower educational levels, median income and higher poverty levels when compared to overall City data. Currently, the crime rate is of great concern in the River South neighborhoods. This alone has caused many neighborhood areas to rally and work for expanded team efforts with schools, churches, civic organizations and the City for revitalization to strengthen its viability and discourage criminal activity [8]. 


\subsection{San Antonio (Franciscan) Missions}

The Catholic Church and the Spanish government established five mission compounds and a small military base in the 18th century that established today's San Antonio, Texas. These missions blended native traditions with newly adopted Spanish ways, and created a very unique culture. The communities still remain in the area and are a very important part of San Antonio's rich cultural heritage [6].

San Antonio Missions Historic District, located along the San Antonio River in the south section of the city, includes the lower four missions (Listed from north to south: Concepcion, San Jose, San Juan Capistrano, and Espada), their acequias and fields. The area originally attracted both prehistoric Indian and historic Spanish and Anglo populations because of the prevalence of unique natural resources. The abundant water, game, and other natural foods seem to have provided prehistoric Indians with an ample non-agricultural subsistence type of lifestyle based upon hunting, gathering, and fishing. The area was utilized for agricultural purposes as well as local industries after the establishment of the Spanish Missions [9]. The Outstanding Universal Value of the Missions is stated below from the World Heritage Nomination Draft Report:

The San Antonio Missions cultural landscape is the best extent model of the culmination of Spain's design for its mission empire. It includes five Spanish Colonial mission complexes (including the Alamo), situated along a 19.3- kilometer section of the San Antonio River basin. Within this fertile stretch of land are found beautiful churches that were centers of the efforts to evangelize and convert the natives. More important to the Spanish Crown, however, was to create self-sustaining, socio-economic units. The Spanish Crown established and supported missions as transitory ecclesiastical settlements that would develop into permanent secular communities in defense of the territory against incursions by other European states. This serial nomination encompasses all the components that were necessary to achieve this socio-economic goal including conventos, native housing, perimeter walls for protection, and a sophisticated irrigation system with dams, an aqueduct and many kilometers of acequias. In addition, it features a granary, an operating horizontal mill, dug wells, farm fields, provision for herds and other support features. Beyond the goal of spiritual conversion, the Crown's ideal of permanent settlements of Spanish-speaking citizens, loyal to the Crown and church, eventually succeeded here and became the model for future missions in Mexico and California [10].

\subsection{World Heritage Site designation}

The World Heritage Site (WHS) nomination of the San Antonio Missions will be reviewed in 2015. It would be the first World Heritage site in the State of Texas and only the $22^{\text {nd }}$ World Heritage designation in the United States [11]. Recognition as a World Heritage Site would put the missions in the company of 
fewer than 1,000 places around the world that are recognized for outstanding historical, artistic, scientific, or natural values [12].

WHS status could bring enhanced resources for conservation and additional funding and investment, and benefit nearby communities from increased visitation and tourist spending. These communities could also contribute to local economic development and revitalization [6]. The new report on potential economic impact of WHS designation funded by Bexar County indicates that WHS designation could be both an outstanding promotional opportunity and a high-profile catalyst for developing more significant cultural and heritage tourism in the area. The Harbinger Consulting Group [6] states, "Cultural travelers, whether domestic or international, look for experiences that are unique to a place. The World Heritage Site can be used to capture the attention of these potential visitors, but they will be looking for other high quality, engaging, authentic cultural experiences to augment their WHS visit. Use WHS designation as a catalyst for developing and connecting other heritage tourism opportunities and local businesses."

Three significant improvements around the San Antonio Missions are coming together which will give the World Heritage application a major boost; they include:

- \$15.5 million in improvements and an endowment for the Mission churches sponsored by the Las Misiones, a non-profit entity

- \$358 million San Antonio River improvement project managed by the San Antonio River Authority and funded by Bexar County, City of San Antonio and US Corps of Engineers

- \$4 million San Juan Demonstration Farm funded by Bexar County and Los Compadres de San Antonio Missions [11] - Expected to be operational in 2013, the farm could attract more than 240,000 visitors to a demonstration Spanish colonial farming interpretive program [5].

As the river trails and mission portals are completed, and projects such as the demonstration farm at Mission San Juan come online in the next few years, visitor activity is projected to steadily increase [5]. Ten years after presumed designation of the Missions WHS (2025), annual economic benefits for Bexar County are expected to range from 11 to 26 percent above the impacts the Alamo and San Antonio Missions National Historical Park would generate regardless of World Heritage status. Economic benefits grow with collaboration, promotion, and use of the WHS to catalyze additional cultural heritage tourism [6].

\section{Authenticity in the Missions Historic District}

Cultural heritage tourism is traveling to experience the places and activities that authentically represent the stories and people of the past and present [1]. It is an economic development tool designed to attract visitors to an area based on the unique aspects of the locality's history, landscape and culture. This not only boosts regional and local pride but is also a good source of revenue for a community and creates jobs. The World Tourism organization UNWTO estimated in 2006 that 35 to 40 percent of tourism represents cultural tourism or 
heritage tourism. Lyon and Wells [2] states "As an alternative to mass tourism, cultural and heritage tourism offer opportunities for place-based engagement that frames contexts for interaction with the "lived space" and "everyday life" [3] of other peoples as well as sites and objects of global historical significance."

Two major components of cultural heritage are integrity and authenticity.

\section{Integrity}

In historic preservation, integrity is the ability of a property to convey its historic significance [13]. The elements of integrity are defined in the National Register Bulletin 15 as well as the World Heritage Operational Guidelines. Professionals engaged in preservation design and planning use these recognized standards and guidelines to define the historic significance and determine the appropriate treatments to protect the integrity of the cultural heritage. State and local governments use the professional standards, too. Cities such as San Antonio enact ordinances to protect the physical integrity of buildings and districts that the City has designated as historic. The protection of the designated properties happens through a process of review and approval. In San Antonio, as in almost all US cities, the referenced standard for review of proposed changes is the US Secretary of the Interior's Standards for the Treatment of Historic Properties (rev. 1995). This is the City's primary tool to protect the cultural heritage from real estate development that might otherwise alter or destroy the elements of the built environment that they designated as valuable. Adjacent to and surrounding the four San Antonio Missions that comprise the National Historical Park, is the vast Missions Historic District designated and protected by the City.

\section{Authenticity}

Authenticity is the degree to which a historic site and its surrounding context convey information about the past honestly and accurately. Authenticity is a quality of great importance to cultural heritage tourism. The tourist seeks two basic types of authenticity, 1) material form (i.e. integrity), which is a tangible authenticity; and 2) the quality of experience, which is an intangible authenticity. Authenticity is integral with integrity, and both are defined in the World Heritage Operational Guidelines. These Guidelines are particularly relevant to the San Antonio Missions and the Missions Historic District because the Missions are currently in the process of a World Heritage nomination.

\section{Intangible Heritage}

The field of historic preservation also recognizes values that go beyond the tangible built environment - intangible values. These are found, for example, in traditions and events of places. The "Mariachi Mass" that occurs in the sanctuary of the Mission San Jose church every Sunday at noon is such an example of intangible heritage value. These intangibles are part of the authenticity and integrity of a place. Together with the tangible values of real buildings and objects, the intangible values define the levels of authenticity and integrity.

\section{Outstanding Universal Value}

The central criterion for inscription as a UNESCO World Heritage Site is Outstanding Universal Value (OUV). The two categories for comparative measure of OUV are authenticity and integrity. To be eligible for World Heritage 
designation, authenticity must be truthfully and credibly expressed. A range of authenticity and integrity attributes are defined in the Operational Guidelines, and these are used in the chart below to show which ones are present in San Antonio and to what degree. All of these attributes have potential market value for heritage tourism.

\section{Heritage Tourism: Cultural Resources and Market Values}

The built environment functions as a resource (economic asset) in the case of San Antonio. Today, the City receives 28 million visitors annually. Recent scholarship in the field of cultural geography defines heritage as something that is applied as a resource or asset by present-day users. "The past, transformed into heritage, is a ubiquitous resource with many contemporary cultural, economic and political functions" [14]. Resource is a word commonly used in the parlance of the historic preservation field, as well, wherein documentation and planned retention of cultural significance is all considered cultural resource management [15]. When handled correctly, heritage tourism is big business and has the capacity to transform a region.

\section{The Cultural Landscape of the San Antonio Missions}

Two related questions need to be considered here. Why are the San Antonio Missions considered eligible for inscription as a World Heritage Site, and what is it that the tourists come to experience? The individual buildings are part of this, in particular the chapels and churches of the Missions, but they are not the whole story. The Historic District designated by the City comprises an intact cultural landscape that shows a progression of change over time that is directly connected to the Spanish Colonial history of the place, and retains the authenticity of continuous use by the descendants of the people who created it. As a result, the present cultural landscape has large quantities of the integrity and authenticity that heritage tourists seek.

The San Antonio missions are authentic to a remarkable extent in terms of their locations and settings, forms and designs, materials and substance and use and function.....The two most southerly complexes in the 14.5-km-long chain of missions, Missions San Juan and Espada, are located in remarkably rural settings. In form and design, the missions' traditional Benedictine plan for convents, modified by the Franciscans into a friary plan enclosed within defensive walls, has remained intact.... Four of the five mission churches remain in use today as active Roman Catholic parishes, with some parishioners tracing their roots to the original mission dwellers. Mission Espada's acequia and aqueduct still carry water to serve the area of the mission, as they have done continuously for more than 265 years [10].

For the development of heritage tourism, the existing heritage must be promoted as a tourism resource. Even the plan developed by the City of San Antonio in 1973 had mentioned the tourism potential and the importance of keeping the historic authenticity in the area:

The design of the natural and manmade features of the Mission park should equal the high quality achieved by the Riverwalk. Four unifying themes are suggested to guide the design: historic authenticity, a semirural setting, a small scale of structures and the San Antonio River [16]. 
As noted by Finley [17], "The experience of the authentic is central to the allure of tourism as an industry. Bound up in representations of reality and truth, notions of authenticity are proffered by the actuality of the tourist settings and the actions of the tourists themselves.” This experience includes cultural events, musical traditions, culinary tastes and even the goods sold in retail shops. In short, the authentic experience includes the intangible attributes that come from the people of a place. Without the people, there is no living culture to experience.

\section{Charting the Attributes of Authenticity and Integrity}

Table 1: $\quad$ Attributes of authenticity and integrity of the Colonial Missions in San Antonio. These attributes have market value for heritage tourism.

\begin{tabular}{|c|c|c|c|c|c|}
\hline $\begin{array}{l}\text { Attributes of World Heritage Outstanding } \\
\text { Universal Value (OUV). All OUV values are } \\
\text { relevant to the intact cultural landscape of the } \\
\text { Colonial Missions in San Antonio }\end{array}$ & $\begin{array}{l}\text { Tangibly } \\
\text { embodied } \\
\text { in built } \\
\text { features }\end{array}$ & $\begin{array}{l}\text { Embodied } \\
\text { in the } \\
\text { Local } \\
\text { Population }\end{array}$ & $\begin{array}{l}\text { Degree } \\
\text { Present in } \\
\text { SA }\end{array}$ & $\begin{array}{l}\text { Concern: } \\
\text { tourist \#'s } \\
\text { may } \\
\text { damage }\end{array}$ & $\begin{array}{l}\text { Threat by } \\
\text { insensitive } \\
\text { economic } \\
\text { growth }\end{array}$ \\
\hline \multicolumn{6}{|l|}{ AUTHENTICITY Attributes } \\
\hline $\begin{array}{l}\% \text { of intactness of the physical form and } \\
\text { design }\end{array}$ & Yes & No & High & Concern & No \\
\hline Material surviving from historic period & Yes & No & High & Concern & No \\
\hline $\begin{array}{l}\text { Use/ function survives from the historic } \\
\text { period }\end{array}$ & No & Yes & Low & No & No \\
\hline $\begin{array}{l}\text { Traditions, techniques and management } \\
\text { system surviving from the period of operation }\end{array}$ & No & Yes & Med & No & No \\
\hline $\begin{array}{l}\text { Location/ setting of the buildings survive from } \\
\text { historic period (not reconstructed or moved) }\end{array}$ & Yes & No & High & Concern & Threat \\
\hline \multicolumn{6}{|c|}{$\begin{array}{l}\text { Language and other forms of intangible heritage associated with the place continue to present day (historic culture remains } \\
\text { the dominant culture in the immediate context) RE: a, b, and c below. }\end{array}$} \\
\hline $\begin{array}{l}\text { a. retains a high degree of its historical, } \\
\text { cultural context, i.e. the original culture is still } \\
\text { dominant culture in the immediate context of } \\
\text { the Mission. }\end{array}$ & No & Yes & High & No & Threat \\
\hline $\begin{array}{l}\text { b. buildings and grounds are in regular use } \\
\text { associated with historical functions }\end{array}$ & No & Yes & Med & Concern & No \\
\hline $\begin{array}{l}\text { c. events connected to period of operation } \\
\text { continue today }\end{array}$ & No & Yes & Med & Concern & No \\
\hline $\begin{array}{l}\text { Spirit and feeling (see paragraph } 85 \text { of the } \\
\text { Operational Guidelines) }\end{array}$ & Yes & No & Med & Concern & Threat \\
\hline $\begin{array}{l}\text { Low degree of reconstruction (paragraph } 86, \\
\text { page 22) which means higher authenticity. }\end{array}$ & Yes & No & High & No & No \\
\hline \multicolumn{6}{|c|}{ INTEGRITY: a measure of the wholeness and intactness of the cultural heritage and its attributes. } \\
\hline $\begin{array}{l}\text { Extent to which the property includes } \\
\text { elements necessary to express its OUV }\end{array}$ & Yes & No & High & Concern & Threat \\
\hline $\begin{array}{l}\text { Extent to which the property size ensures full } \\
\text { representation of the features and processes } \\
\text { which convey the property's significance }\end{array}$ & Yes & No & High & No & Threat \\
\hline $\begin{array}{l}\text { Current, physical condition of materials and } \\
\text { systems are good }\end{array}$ & Yes & No & High & Concern & No \\
\hline $\begin{array}{l}\text { Impact of deterioration processes controlled; } \\
\text { permanent maintenance process that avoids } \\
\text { or greatly minimizes reconstruction of } \\
\text { elements }\end{array}$ & Yes & No & High & Concern & No \\
\hline $\begin{array}{l}\% \text { of elements necessary to convey the totality } \\
\text { of the value conveyed by the property is high; } \\
\text { no question of what might have existed } \\
\text { because nothing is missing }\end{array}$ & Yes & No & Med & No & No \\
\hline $\begin{array}{l}\text { Relationships and dynamic functions in } \\
\text { cultural landscapes, historic towns or living } \\
\text { properties essential to distinctive character } \\
\text { are maintained. }\end{array}$ & Yes & Yes & High & Concern & Threat \\
\hline
\end{tabular}




\section{A community-based cultural Heritage Tourism Project in the Missions Historic District}

Heritage includes the natural as well as the cultural environment - landscapes, historic places, sites and built environments, as well as biodiversity, collections, past and continuing cultural practices, knowledge and living experiences [18]. Most countries encourage the preservation of heritage as an asset for all, used to arouse a sense of continuity of culture, enrichment of people's lives, as a link with the past and to allow society to make sense of the present [19].

The visitor experience is greatly enhanced due to the "authenticity" of the destination and capitalization on the growing trend of "giving back to the community." Direct involvement of the community in tourism development encourages an awareness of, and pride in, community assets - the culture, heritage, cuisine and lifestyle - and this fosters community based conservation of the assets [20], and at the same time enables that community to be pro-active in developing what it sees as 'unique' in terms of developing an appropriate cultural heritage tourism strategy for the area [21].

Stakeholders are becoming increasingly important in heritage management and planning, especially the community as owner and custodian of heritage. People in the community need to be involved in the development of the cultural resource, and convinced of the merits of working together to generate income for preservation. They have to be aware of the impacts of tourism - like loss of authenticity - and thus the need for planning [22].

Within this frame the development of community-based cultural heritage tourism is critical. Community-based cultural heritage tourism includes levels of community ownership, levels of investment, levels of local job creation, levels of active involvement by local community members and the financial returns to local people [23]. Expected outcomes from a community-based program include:

- Creating jobs through the development of a tourism infrastructure,

- Developing new, and enhancing current, tourism products,

- Providing training and capacity building, and

- Ensuring that the projects are sustainable in the long term [23].

Experiences of community-based tourism seek to achieve sustainable development, thus communities can improve their living conditions without disappearing and/or losing their authenticity, and without irreversibly damaging the environment [24].

In this context, the Center for Cultural Sustainability has proposed a community-based cultural heritage tourism project in the Missions Historic District as a unique development model. A group of faculty with an expertise on architecture and planning, conservation, business, and tourism, have worked together and developed a community-based cultural heritage tourism model. This model is just a project proposal now to be developed further when funded.

The concept is to engage District residents in small business development to create prosperity for residents. It means to promote the continuity of heritage through the benefits which come from cultural heritage tourism. The project aims to provide technical preservation and conservation guidance, and cultural 
heritage tourism knowledge to potential small business owners in reuse of existing, historic buildings and properties for new businesses. Prospective entrepreneurs would receive training and professional support to tap into the tourist economy, and in turn, their efforts would support and sustain the cultural heritage and identity of their community. The proposed model addresses the issues of cultural and environmental sustainability at the local level while giving tourists an option to experience the cultural heritage of the region.

This project focuses on the potential of new business uses for existing buildings and properties in the Missions Historic District, while planning sustainable, opportunity rich, and economically competitive communities. Proposed projects promote cultural and environmental sustainability at the local level while giving tourists an option to experience the cultural heritage of the region.

This project aims to provide individual property owners with a package of offerings. Highlights include:

- training workshops on Cultural Heritage Tourism including coverage of the financial aspects of Heritage Tourism

- training on preservation (rehabilitation) of existing buildings.

- business plans for small business owners, including marketing plans, social media, and information on area micro-lenders.

- architectural design as well as workshops and services geared to revitalization efforts

In order to create a plan with the greatest opportunity for success, the project group would engage with the local community to ensure that professional and scholarly collaboration is led by the community's vision for their own prosperity. During this model project, selected entrepreneurs would be trained on how to fund, start-up and run a small business focused on cultural heritage tourism. By the conclusion, they would also be done with the construction and/or renovation of their own properties.

\section{Conclusion}

The San Antonio Missions have always been a tourist destination. Even in the 19th century, when the missions were mostly in ruins, they were attracting tourists. After the Missions were restored in the early 20th century they once again became active parishes in the midst of neighborhoods. Now they are focal points for new economic development along the river redevelopment.

Unfortunately the impact of those visitations has not really translated to positive economic development for the local community. The proposed community-based cultural heritage project would highlight the tourism potentials of the site, capitalize the public investments and improvements around the San Antonio Missions, and encourage the revitalization of the Missions Historic District. The area will regain its sense of identity and share its treasures of history, culture and heritage with all who visit and seek for authenticity.

World Heritage Site designation could be both a promotional opportunity and a high-profile catalyst for developing more important cultural heritage tourism in 
the Missions Historic District [6]. World Heritage inscription can bring increased tourism with both positive and negative impacts. Tourism can bring many benefits to a local economy but it can also disturb the quality of life of the local residents. Throughout this development process, if the Missions Historic District is not well managed it may lose its authenticity and thus its attractiveness to visitors [25].

In this respect, the proposed community-based cultural heritage project is very important and timely in order to support and connect community small business owners to the existing heritage tourism economy while planning the upcoming inevitable tourism development as well. It is expected that successful local businesses in the District would encourage other local business entrepreneurs on their initiatives, and in return this would cause a ripple effect. Especially if a broad community partnership takes advantage of proposed opportunities, it could develop significant economic benefits linked to WHS status [6]. Promoting cultural heritage tourism in the District and creating prosperity for its residents would strengthen the area's viability and discourage problematic criminal activity. The proposed model would benefit the community members with educational projects, trainings, and other tourism revenues. Finally, this unique development opportunity would encourage local people to rehabilitate their existing properties, improve the quality of their life, and ultimately prevent gentrification and loss of authenticity by sustaining the cultural heritage and identity of their community.

\section{References}

[1] National Thrust for Historic Preservation, Heritage Tourism, http://www.preservationnation.org/information-center/economics-ofrevitalization/heritage-tourism/\#.UTO_fTk_644 (accessed 03/03/2012).

[2] Lyon, S.M. and Wells, E.C., 2012. "Ethnographies of Global Tourism: Cultural Heritage, Economic Encounters, and the Redefinition of Impact”, Global Tourism: Cultural Heritage and Economic Encounters, AltaMira Press, UK, pp. 1-21.

[3] Lefebvre, H. 1974. The Production of Space, Wiley-Blackwell, London, UK.

[4] Fisher, L.F., 2007. “Overview”, San Antonio Architecture, Traditions and Visions, AIA San Antonio, pp. 7-11.

[5] UTSA Institute for Economic Development's Center for Community and Business Research in conjunction with The Harbinger Consulting Group, 2011. Economic Impact of the San Antonio Missions, National Historic Parks, http://ccs.utsa.edu/pdf/EconomicImpactMissions.pdf (accessed 03/03/2012).

[6] The Harbinger Consulting Group, 2013. Building on a Strong Foundation: Potential Economic Impact of World Heritage Site Designation for the San Antonio Missions, http://www.bexar.org/whs/Missions_WHS_Report.PDF (accessed 03/03/2012). 
[7] City of San Antonio, Office of Historic Preservation. A Guide to San Antonio's Historic Resources, http://www.sanantonio.gov/historic/Docs /DesignGuidelines/7_GuidetoSanAntonio’sHistoricDistricts.pdf (accessed 03/27/2012).

[8] San Antonio River South Area Coordinated Management Plan, ProtectPromote-Coordinate, 2010. http://www.sanantonioriver.org/images/ RiverSouth_Management_plan_12_08_2010.pdf (accessed 03/03/2012).

[9] City of San Antonio, Office of Historic Preservation, Local Historic Districts, Mission, http://www.sanantonio.gov/historic/Districts/ Mission.aspx (accessed 03/03/2012).

[10] San Antonio Franciscan Missions, 2013. World Heritage Nomination Draft, Unpublished paper, San Antonio, Texas.

[11] 2012. "San Antonio Community Leaders Launch, Quest for World Heritage Status”, August 22, U.S. Department of the Interior, National Park Service, http://www.nps.gov/saan/parknews/world-heritage-quest.htm (accessed 03/27/2012).

[12] UNESCO World Heritage Center, Tentative List: San Antonio Franciscan Missions, http://whc.unesco.org/en/tentativelists/5247/ (accessed 03/03/2012).

[13] National Register Bulletin 15, "How to Apply the National register Criteria for Evaluation”, U.S. Department of the Interior, National Park Service, http://www.nps.gov/nr/publications/bulletins/pdfs/NRB15.pdf $\quad$ (accessed 03/27/2012).

[14] Ashworth, G., Graham, B., Tunbridge, J., 2007. Pluralising Pasts: Heritage Identity and Place in Multicultural Society, London: Pluto Press.

[15] Fitch, J. M., 1990. Historic Preservation: Curatorial Management of the Built World, Charlottesville: University Press of Virginia.

[16] Missions of San Antonio, City of San Antonio, Comprehensive Planning Division, Community Development Office, July 1973.

[17] Finley, C., 2004. “Authenticating Dungeons, Whitewashing Castles: The Former Sites of the Slave Trade on the Ghanaian Cost", Architecture and Tourism, Berg.

[18] 1999. International Cultural Tourism Charter, Managing Tourism at Places of Heritage Significance, ICOMOS International Council on Monuments and Sites, Mexico, http://www.icomos.org/charters/tourism_e.pdf (accessed 03/27/2012).

[19] Cros, H., 2001. “A New Model to Assist in Planning for Sustainable Cultural Heritage Tourism”, International Journal of Tourism Research, Volume 3, Issue 2, March/April 2001, pp. 165-170.

[20] Bhattacharya, B., Ganguly, C., 2011. Community Initiatives in Achieving Sustainability Through Inclusive Tourism Practices, Conference on Inclusive \& Sustainable Growth Role of Industry, Government and Society Conference Proceedings, Institute of Management Technology.

[21] Millar, S., 1989. "Heritage Management For Heritage Tourism”, Tourism Management, Volume 10, Issue 1, March 1989, pp. 9-14. 
[22] Aas, C., Ladkin, A., Fletcher, J., 2005. "Stakeholder Collaboration and Heritage Management”, Annals of Tourism Research, Volume 32, No. 1, pp. 28-48.

[23] Leballo, M., 2000. "The Study of Best Practice in Community-Based Tourism Initiatives (CBTI) in South Africa”, Unpublished paper, Land and Agricultural Policy Center, Johannesburg.

[24] Ruiz-Ballesteros, E., 2011. "Social-ecological Resilience and CommunityBased tourism: An Approach from Agua Blanca, Ecuador”, Tourism Management, Volume 32, Issue 3, June 2011, pp. 655-666.

[25] Brooks, G., 2008. "Exploiting the Benefits of World Heritage Listing: Evora, Portugal and Hoi An, Vietnam”, City Spaces - Tourist Places: Urban Tourism Precincts, Elsevier, UK. 